\title{
Survival of Drogpa Cultural and Traditional Memes and the Threat of Modern Development
}

\author{
Dorji Wangchuk $^{1}$, Wanchai Dhammasaccakarn ${ }^{1} \&$ Punya Tepsing ${ }^{1}$ \\ ${ }^{1}$ Faculty of Liberal Arts, Prince of Songkla University, Hat Yai, Songkhla, Thailand \\ Correspondence: Dorji Wangchuk, Faculty of Liberal Arts, Prince of Songkla University, Hat Yai, Songkhla \\ 90112, Thailand. E-mail: dwzamin@gmail.com
}

Received: June 16, 2013 Accepted: August 15, 2013 Online Published: October 29, 2013

doi:10.5539/ass.v9n15p142 URL: http://dx.doi.org/ass.v9n15p142

\begin{abstract}
This paper examines the impact of modern amenities such as roads, electricity, cell phones, television, and tourism on the two Drogpa communities of Me rag and Sag steng. It also aims to study the misinterpretation of ancient Drogpa history. The paper concludes that the endurance of Drogpa culture is uncertain and thus, loss of their identity is imminent in the near future. Therefore, the future of Drogpa culture and their hospitable behaviour will depend on how well they perceive and respond to the modern developments. Finally, this paper concludes that the government of Bhutan and Drogpa should proceed collaboratively to sustain their valuable culture and traditions. Furthermore, government should also examine methodically prior to executing any development activity to make certain that tribal cultures be endorsed and more tribal youths be encouraged to acclimatize to their cultures and traditions.
\end{abstract}

Keywords: Bhutan, biography, culture, Drogpa, modern development

\section{Introduction}

Should Brogpa (Tib. 'brog pa) (Wangmo, 1990; Chand, 2000, 2004, p. 1; Dorji, 2002; Pelgen, 2003; Dompnier, 2007, pp. 6-11; Bhattarai et al., 2011; Wangchuk et al., 2012) or Drogpa (Central Tibetan dialect: 'drog pa) (Karchung, 2011) uphold their unique culture and hospitable behaviour along with the modern developments? Drogpa have access to modern amenities such as roads, electricity, mobile phones, television, and cooking appliances, marking the commencement of acculturation. Therefore, the sustainability of Drogpa culture and behaviour is an enormous challenge in this technologically advancing world whereby the influential cultures of West are being adopted by the people and eventually modifying the existing age-old cultural and traditional memes (White, 1959; Bowler, 1990; Banerjee, 1998; Groenfeldt, 2003; Chand, 2000; Dompnier, 2007, p. 1; Karchung, 2011).

Among the various ethnic groups of people residing in Bhutan-e.g., Monpas of Wangdue Phodrang, Trongsa, Zhemgang and Dagana regions, Toktops of Chhukha district, Doya (Lhops), Taba and Dramtoep of Samtse district, Khengpa of Zhemgang district, Bjop of Gasa district and Drogpa of Me rag (pronounced as Merak) and Sag steng (pronounced as Sakteng) regions (Chakravarti, 1981, p. 18; Noble, 1984, p. 12; Gyamtsho, 2000; Chand, 2004, pp. 24-25, 2009; Chettri, 2008; Dorji, 2008, p. 5; Karchung, 2011; Wangchuk et al., 2012) are culturally distinct. Drogpa constitutes indubitably a unique tribe of Eastern Bhutan (Wangmo, 1990; Chand, 2000; Dompnier, 2007, pp. 6-11). They possess exclusive and inimitable cultures, traditions and behaviour that have cradled all the way through their successive generations of the mythical bird (Garuda (Byachung)) kings Dabzang ('dab bzang) and Shogzang (Gshog bzang) (Chand, 2000; Pelgen, 2003; Dompnier, 2007, pp. 12-15) and Ama Jomo Remati (Pelgen, 2003) or Ama Jomo (Wangmo, 1990; Dompnier, 2007, p. 1), also referred to as Khamsang Ama Jomo (Karchung, 2011). They depend on the herds of yaks and sheep for their livelihood. Drogpa are categorized as semi-nomads/pastoralist because the herders (Nag rdze; pronounced as "Na ze")-each house has 1 or 2 Nag rdzes depending on herd size-practice seasonal migration (Wangmo, 1990; Chand, 2000; Dompnier, 2007, p. 36) and rest of the people have permanent settlements in various parts of Me rag and Sag steng geogs (a block level administrative unit). 


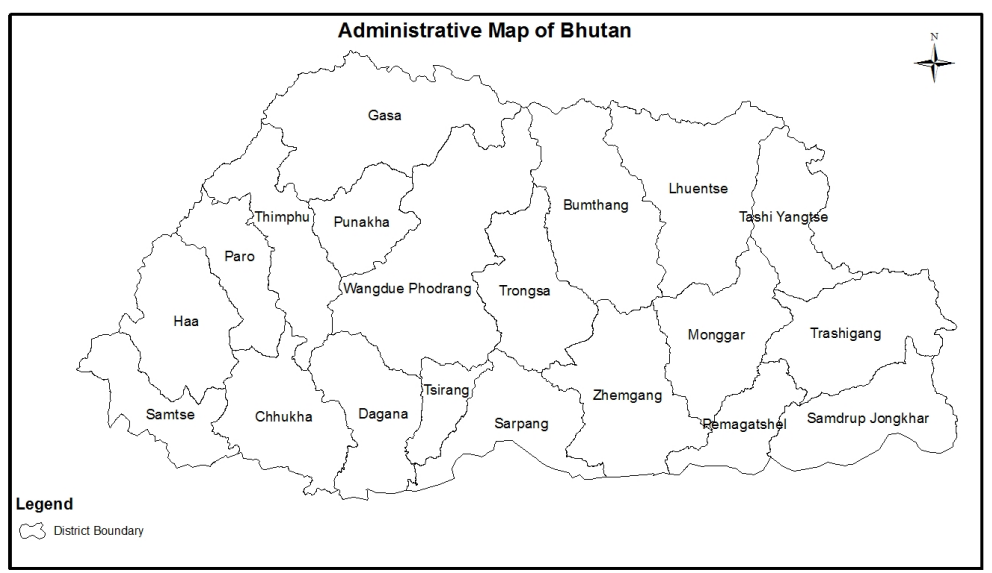

Figure 1. Administrative map of Bhutan

Source: Phuntsho (2013)

The significance of this paper is that, it discusses on the culture, traditions and behaviour of Drogpa that are changing hastily along with the globalizing world. Therefore, we will present the successive changes of Drogpa culture, traditions and behaviour as a result of modern developments, and we expect that it would provide a wider depiction of Drogpa transformation to the readers concerning how indigenous cultures, traditions and behaviours are overwhelmed and endangered by the global culture (see Groenfeldt, 2003; Triandis, 2006; Hosseini, 2010; Karchung, 2011).

To comprehend the influence of globalization on Drogpa culture, traditions and behaviour we browsed adequate journal papers concerning about the tribes in the world. We have analyzed those papers in-depth to examine the impact of globalization on Drogpa and other tribal people and ultimately portrayed their future consequences. To understand their history we referred available rNam thar (biographies: pronounced as Namthar) viz. (1) "Rang reị pha mes kye byung kungs mkha lding kyung gi gdung rbas chung brjod par bya ba ni//"; (2) " 'dul ba lung las byung baị byaị rgyal po "dab bzang dang Gshog bzang gi mi rbas byung tsul mdor bsdus bzhug so//"; (3) "Me rag blama Bsten peị sgron mi yi mdzad rnams dang dgron gnas chags tsul ä sam rgyal po nas khrl dang sa cha dbang baị hjon yig dor hdus bzhugs so//" and (4) the epic of King Geser (Ge gser) of Ling.

\section{Methodology}

For this study, we have emphasized a lot on those existing biographies of the Drogpa to understand their true history. Those biographies were translated in English to review in depth. We also browsed adequate papers on Drogpa studies to understand their past. An observation method was also applied to understand Drogpa behaviour and their reaction towards the modern amenities.

\section{Drogpa Commentary (A History as Narrated in the Biographies)}

It is difficult to generalize when Merak (Wangmo, 1990; Chand, 2000, 2004, p. 1; Dompnier, 2007, p. 1; Bhattarai et al., 2011; Wangchuk et al., 2012) or Me rag (Dorji, 2002; Pelgen, 2003; Karchung, 2011) and Sag steng were peopled. In fact, it is uncertain when Drogpa left Tibet for Bhutan. In order to draw adequate and legitimate information on Drogpa history, one has to consider the biography of various kings of Tibet and eventually trace causal linkages with Drogpa rNam thar. The assumption on the date of departure of Drogpa from sKom rLon Rogs gsum can be traced through a brief account of Mongol assault in Tibet during the reign of Chogyal Pelzang (Bya Chos rgyal dpal bzang) (Dompnier, 2007, pp. 12-15). This Mongol invasion is referred to the maneuver of Chengiz Khan or Genghiz or Jenghiz or Jengiz Khan (1155 A.D-1227 A.D) (Nehru, 2004, pp. 250-254) of $13^{\text {th }}$ century (Dompnier, 2007, pp. 12-15). Taking into the account of the Mongol incursion of $13^{\text {th }}$ century, King 'Gya bzang and Blama Bya ras pa might have lived in Mtsho snar either during $14^{\text {th }}$ or $15^{\text {th }}$ century (Dompnier, 2007, p. 14; as cited in Wangchuk et al., 2013). According to the chronological pedigree, Blama Bya ras pa (pronounced as Lama Jarapa) is considered as the fourth successive generation of Chogyal Pelzang (Great great grandfather of Blama Bya ras pa).

The history of Drogpa is based on both the written documents (rNam thar-biographies or manuscripts) and oral 
traditions (Wangmo, 1990; Dompnier, 2007, p. 1). However, due to lax behaviour of people the oral traditions are misinterpreted and misarticulated thus losing the aboriginal values. Therefore, the manuscripts (rNam thar) (Dompnier, 2007, p. 1) are only reliable sources of information. Those rNam thar-"Sag steng Pai Jung Rab" (Dompnier, 2007, p. 12) synonymously referred to as "Rang reị pha mes kye byung kungs mkha lding kyung gi gdung rbas chung brjod par bya ba ni//" by Pelgen (2003) and " "dul ba lung las byung baị byaị rgyal po "dab bzang dang Gshog bzang gi mi rbas byung tsul mdor bsdus bzhug so//"; meaning the origination history of human race all the way through the mythical bird (Garuda; Byachung) kings Dabzang (ibid) and Shogzang (Pelgen, 2003)-is written by a monk from Man, Tawang (Arunachal Pradesh, India) called Lama Wang (Blama Dbang) during the $18^{\text {th }}$ century (1747) (Dompnier, 2007, pp. 12-15). The later one is documented by Sersang Lama Gyaltsen Dorji (Gser srang blama rgyal mtsan) during the $19^{\text {th }}$ century (Dompnier, 2007, pp. 12-15).

According to the rNam thar, Drogpa of sKom rLon Rogs gsum villages of Mtsho snar were governed by a megalomaniac monarch-'Gya bzang (Yazang: cf. Wangmo, 1990; Pelgen, 2003; Chand, 2004, p. 36; Dompnier, 2007, pp. 12-15). During his reign, a descendent of the bird kings (Dabzang \& Shogzang) named Blama Bya ras pa (son of Bya Don drub) was also there at Mtsho snar (Dompnier, 2007, pp. 12-15). On one occasion the king 'Gya bzang commanded the people of sKom rLon Rogs gsum (pronounced as Kom Lon Rog Sum) to level the summit of mountain that was blocking his fortress (Mkar gdong rdzong: pronounced as Khardung Dzong) from sunshine. Drogpa worked determinedly for days and nights, yet the outcome was insignificant. Such craving persona of rgyal po 'Gya bzang infuriated the people and they were therefore left in quandary (cf. Wangmo, 1990; Chand, 2004, p. 36; Dompnier, 2007, pp. 16-25). Manuscript annotates that it was at this occasion a woman (Wangmo, 1990) carrying a baby (Pelgen, 2003) or a boy ( Dompnier, 2007, p. 18)-believed to be an emanation of Ama Jomo-appeared amongst those workers and told "ao lo lo, ao lo lo.....ri mgo gcaod pa las mi mgo gcaod pa bla" which means, instead of cutting off the head of mountain it is easier to cut off the head of a man (see Wangmo, 1990; Chand, 2004, p. 36; Dompnier, 2007, p. 18). All those workers were astounded and wondered who could be the woman. Having analyzed what the woman said, they came to know she was no other than Ama Jomo Remanti and instantaneously plotted for conspiracy. The assassination was successful, however, the Drogpa of sKom rLon Rogs gsum were scared to stay in their villages. Therefore, people made their obeisance to Blama Bya ras pa (from Lata; Dompnier, 2007, p. 73) to take them to another place where they could stay in tranquility.

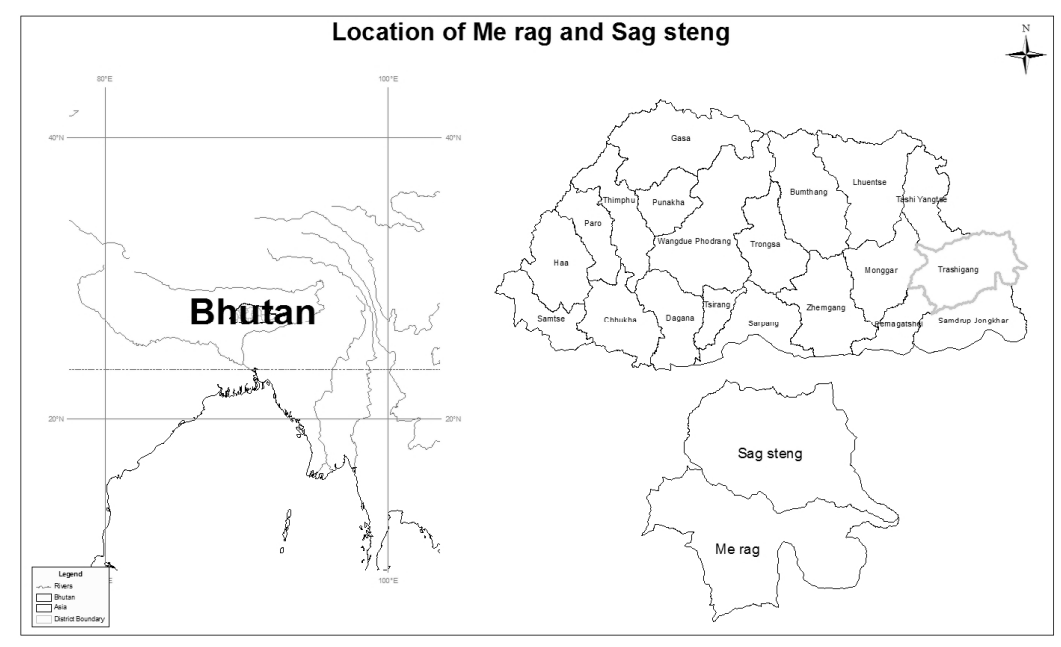

Figure 2. Location map of Me rag and Sag steng

Source: Phuntsho (2013)

Blama Bya ras pa, however in response, told them, he cannot escort alone; rather he recommended the people to seek help from (worship) Ama Jomo Remanti. However, Dompnier (2007, p. 73) elucidated otherwise: It was Ama Jomo Remanti who made a request to Blama Bya ras pa to escort them. This could be miss-communicated oral history because rNam thar $\left(8^{\text {th }}\right.$ folio of "Rang rei pha mes kye byung kungs mkha lding kyung gi gdung rbas chung brjod par bya ba ni//") mentions that Blama Bya ras suggested people of sKom rLon Rogs gsum to seek help from Ama Jomo Remanti. Nonetheless, it is not mentioned in rNam thar how she became their deity. 
According to Dompnier (2007, p. 73) Ama Jomo Remanti was a nun at Ralung (Tibet) who had profound wisdom and also took an oath to lead celibacy life. However, she got married and became a mother. According to the biography of sGrub dbang grags pa rjai btsun (pronounced as Drubwang Drakpa Jitsun: alias sLob dpon Khyi bzhis: pronounced as Lopon Khizhey) of rkang pa ra (rkang: foot; pa ra; print) it was he (sGrub dbang grags pa rjai btsun) who subdued Ama Jomo Remanti and appointed her as the chief of deity (cf. Dompnier, 2007, pp. 72-75). sGrub dbang grags pa rjai btsun is the reincarnation of Prince Kintu Legpa; son of 'Mkha 'gro 'gro ba bzang mo (pronounced as Khando Drowa Zangmo) and King 'Bka la dbang po (pronounced as Kala Wangpo) of Tibet.

Blama Bya ras pa and Ama Jomo Remanti decided to leave sKom rLon Rogs gsum for Drogpas' wellbeing. They brought all their properties-food, yaks and horses-including the scriptures (Buddhist cannons) written in gold (Gser gyi glegs bam) with them (Wangmo, 1990). These people travelled through Tawang to Me rag-Sag steng searching for new homeland. The ruins of settlements they developed along their routes can be seen even today (Wangmo, 1990; Dompnier, 2007, pp. 12-15).

The band of Drogpa led by Blama Bya ras pa and Ama Jomo Remanti eventually arrived at Sag steng. Sag steng was covered with bamboos and people settled in the valley. Accordingly, the village was named Sag steng (Sag: bamboo; steng: on top). Due to the abundance of rhododendrons, Sag steng is also referred to as Bal yul Tama Jong (meaning the paradise of rhododendrons) (see Dompnier, 2007, p. 8). On the contrary Dompnier (2007, pp. 15 \& pp. 74) provides different interpretation; 'Sa' (in dzongkha (Bhutan's national language)) meaning-land/earth (however, the word "Sag" is different from the word "Sa") and steng: on top. Generally, Sag steng is referred as "plain of bamboo" (Wangmo, 1990; Pelgen, 2003; Chand, 2004, p. 37).

As mentioned by Wangmo (1990) Drogpa had to run away to Me rag when a mob of Tibetans approached Sag steng. While escaping from the Tibetan horde Drogpa had to cross a pass (la) named Nyag caung la (approximately 4500 meters above mean sea level). For old, young children and those disabled Drogpa it was difficult to climb over the pass and therefore Blama Bya ras pa and Ama Jomo Remanti had to send them back to Sag steng (Wangmo, 1990). The place from where they were sent back came to be known as Log 'gro jong (Tib. Log 'gro: to return; and Jong: place). Eventually, only those physically strong Drogpa managed to cross Nyag caung la and arrived at a place covered with perchance by dwarf junipers. To convert it into settlement they set on fire the whole area and named it "Me harg" ((Drogpa kha skad): Drogpa language)-set on fire. Due to mispronunciation "Me harg" is called Me rag or Merak these days.

\section{Significance of Drogpa Culture}

Cultural perpetuation in Bhutan is sustained through a distinctive epistemology. The country upholds its dynamic cultures adopting one of the pillars-Preservation and Promotion of Culture-of the development philosophies of the Gross National Happiness (GNH) of Bhutan (Groenfeldt, 2003; Zangmo, 2004, p. 629; McDonald, 2005; Karchung, 2011). Also, the article 4 of the Constitution of the Kingdom of Bhutan considers culture as an indispensable element to enrich socio-cultural values (Kuensel, 2008, p. 8; cf. Karchung, 2011). Thus, culture in Bhutan is of high priority (Karchung, 2011). On the other hand, traditional cultures seem less acceptable in other parts of the world due to its hindrance on development (Mancall, 2004, p. 25). For instance, Chinese Cultural Revolution posed threat on age old traditions and culture and formed new one much appropriate to the contemporary development (ibid).

Bhutan is considered as the home of an assortment of indigenous cultures (Chand, 2009; Karchung, 2011), and the Drogpa culture is one of the most prominent cultures nowhere else to be seen in Bhutan. Cultural practices in Bhutan are principally associated with Buddhist memes (Dorji, 2008, p. 6; Karchung, 2011). Therefore, cultural norms are of utmost significance without which the true essence of the individual identity seems indistinguishable.

Drogpa culture has its origination from the Bird Kings Dabzang and Shogzang-the Drogpa ancestors. It is further transmitted through their successive generations. Later on Drogpa culture was also strengthened by deity Ama Jomo Remanti. Hence, most of traditional and cultural ethics are associated to Ama Jomo Remanti.

Distinctive Drogpa culture has immense potentiality to earning revenue for the country and themselves through the development of eco-tourism (cf. Gurung \& Seeland, 2008). Similar to the history of other tribal people dwelling in various parts of Bhutan, Drogpa have mesmerizing culture and traditions, such as valuable rNam thar, festivals, songs and dances, marriage customs-chung-gnyen (childhood engagement) and 'khor sdeb pa (pronounced as Khordepa: polyandry/polygamy)-bartering of goods ('bru skor: pronounced as Bukor), prayers and offerings devoted to Ama Jomo Remanti. The values of Drogpa history, culture, and traditions are magnificently prescribed in the works of Wangmo (1990), Chand (2000), Dorji (2002), Dorji (2003), Dompnier 
(2007, pp. 6-11) and Karchung (2011). Their diversified culture and tradition speak a volume of ancient history from Tibet to Bhutan and even some parts of India (Dompnier, 2007, pp. 12-15). Pelgen (2003), on the other hand, has elucidated the rituals and pilgrimage devoted to the deity Ama Jomo Remanti and also the myth of Drogpa. In the continuum, Pelgen (2003) has also emphasized on the fading traditions of Drogpa. Recently, Karchung (2011) has discussed on the diminishing costumes of Me rag pa (people of Me rag) in which the author has questioned about the sustainability of Drogpa attires. Furthermore, Wangchuk et al. (2013) have shared their concern regarding the continued existence of yak herding cultures of the Himalayan tribes-particularly the Drogpa and Bjops.

Drogpa culture is emphasized a lot in the studies of Wangmo (1990), Chand (2000; 2004), Dorji (2002), Dorji (2003), Pelgen (2003), Dompnier (2007) and Wangchuk et al. (2013). Many of these researchers referred to the available rNamthar of the Drogpa. Mostly, the biography of Ama Jomo Remanti is used to refer Drogpa history. However, a few like Dompnier (2007) and Wangchuk et al. (2013) have referred other biographies besides Ama JOmo Remanti's biography, such as (1) "Rang reị pha mes kye byung kungs mkha lding kyung gi gdung rbas chung brjod par bya ba ni//"; (2) " "dul ba lung las byung baị byaị rgyal po "dab bzang dang Gshog bzang gi mi rbas byung tsul mdor bsdus bzhug so//"; (3) "Me rag blama Bsten peị sgron mi yi mdzad rnams dang dgron gnas chags tsul ä sam rgyal po nas khrl dang sa cha dbang baị hjon yig dor hdus bzhugs so//" and (4) the epic of King Geser (Ge gser) of Ling.

\section{Exclusive Drogpa Culture and Traditions}

\subsection{Drogpa Costumes}

The uniqueness of Drogpa costumes perhaps is the only sole reason categorizing them as a distinctive group of people in Bhutan (Wangmo, 1990). The tribal people of Arunachal Pradesh, India-Monpa, Aka and Sherdugpen-also wear similar brand of attires although there are slight differences in clothes and methods of wearing (Chand, 2004, p. 70; Karchung, 2011). Therefore, it is possible that the Drogpa and the tribes of Arunachal Pradesh share a common history of their costume origination or have completely different source of origin. In the available biographies of Drogpa the detail information of their costumes origination is not narrated.

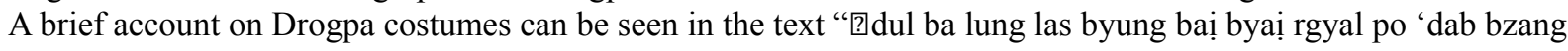
dang Gshog bzang gi mi rbas byung tsul mdor bsdus bzhug so//". Karchung (2011, pp. 37-38) has also described briefly on the history of Drogpa costumes based on some texts, however, he hasn't mentioned the name of the biographies. According to the biography "团dul ba lung las byung baị byai rgyal po 'dab bzang dang Gshog bzang gi mi rbas byung tsul mdor bsdus bzhug so//"and a few village pundits the Drogpa costumes were instigated by the bird kings Dabzang and Shogzang.

However, there are also a few Drogpa who narrate the history of their costumes conversely. They say Drogpa costumes are the dress of Glud (scapegoat) (see Chand, 2004, p. 35). Glud (scapegoat) are those humans believed to possess evil curse and therefore to get rid of a ritual called-Glud gong-, Chand, 2004, p. 35 or Glud gtor is performed using their effigies made out of dough or clay. Some scholars (e.g., Choden, 1997, pp. 3-4; Chand, 2004, p. 35) believed that the people of Laya are descendants of female (Mo) Glud and Drogpa as the descendants of male (Pho) Glud. Such elucidation on Drogpa costumes origination is considered invalid and illogical as per the $18^{\text {th }}$ folio of the rNam thar. The rNam thar explains that the descendants of great eminent bird kings whose generations are all great saints (Blama) can't be sent as Glud in the form of human beings. Drogpa and Layap (people of Laya) of course trace their origin from Tibet but certainly not the descendants of the scapegoats.

As per the biography, rTsid pa zha mo (pronounced as Tsidpa zhamo: black hat made of yak's hair) symbolizes the head of black (Gnag po: pronounced as nagpo) Byachung (Garuda, mythical bird), an assortment of sTod dung-in various colours-signify those sleeves worn by the descendants of bird kings (Karchung, 2011), sPu lham (woolen boots), Pag lham (leather boots) and Btsim lham or also called Mo lham (woolen boots) are considered as feet of Byachung. Lhem pa (see Figure 4) is believed to be the wings of mythical bird. Listening to those oral traditions and going through the rNam thar, it is apparent there must be some texts containing ample details on Drogpa costumes.

Drogpa can be easily distinguished from other tribes of Bhutan by their costumes which are exceptionally distinct. The clothing materials (wool, silk \& yak's hair) indicate that Drogpa costumes are typically designed to help them adopt in the harsh geographical environment (cf. Karchung, 2011). Men wear a jacket called Chu pa (pronounce as ba) in general (Wangmo, 1990; Dompnier, 2007, pp. 38-41; Dutta, 2011)-mostly maroon in colour (rTsha khams Chu pa, formal) and in black (sPuị Chu pa, informal) (Karchung, 2011) tauten around the waist by a sash up to the length of mid-thigh (Chand, 2004, p. 70; Karchung, 2011). Along with Chu pa they put on 
garments such as the Pags tsa (tanned leather of animals like calf of yaks, deer, antelope and even wild goats ), rTsid pa zha mo (five long tufts ( $\pm 15-20$ centimeters) hat made of yak's hair), rKang bgho (alike shorts made of wool), Pi shub (leather leggings), sPu lham and Pag lham (Chand, 2004, pp. 70-74; Karchung, 2011), and of course Dri (knife) tied on left waist is an essential component of their costume. Men are also adorn with earrings (rNam zao proị) made of precious stones (Wangmo, 1990; Dompnier, 2007, pp. 38-41; Karchung, 2011). However, about $90 \%$ of Drogpa do not put on earrings now. Predominantly, it is young Drogpa who seldom wear earrings due to their bashful behaviour.
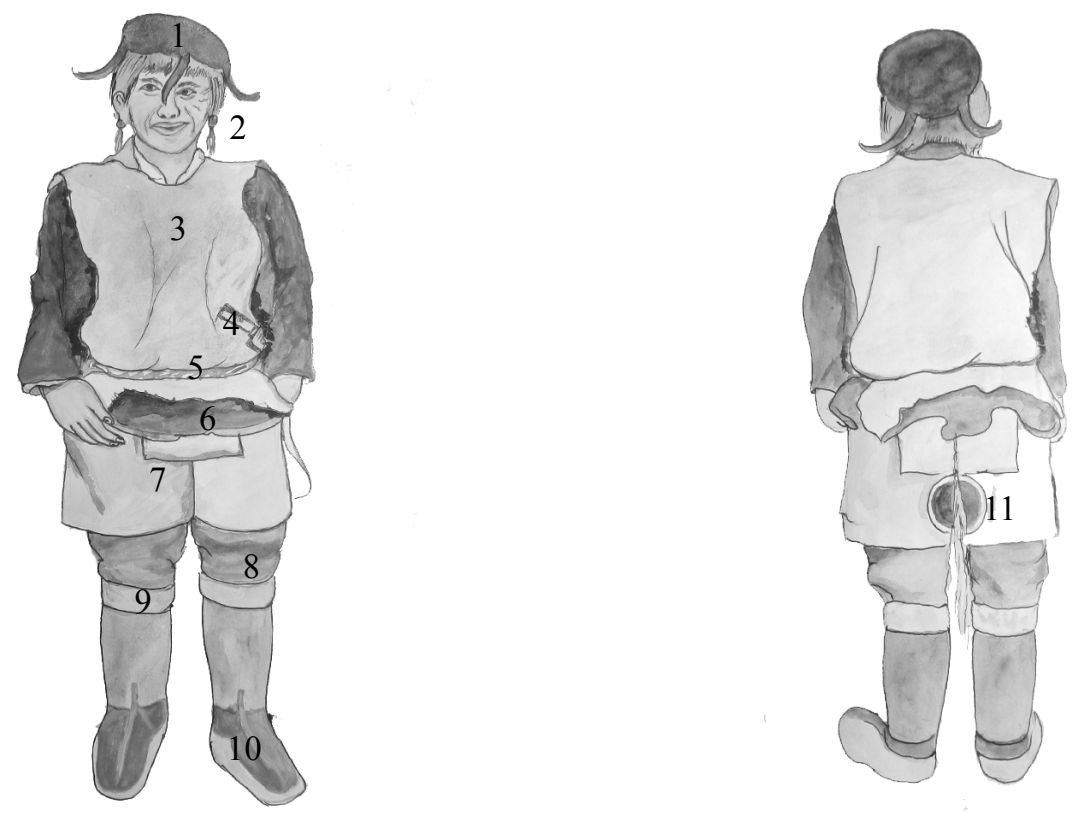

Figure 3. Male Drogpa costume

1. rTsid pa zha mo

2. rNam zao proị

3. Pags tsa

4. Dri

5. sGyid thag

6. Chu pa
7. rKang bgho

8. Pi shub

9. Lham togs

10. sPu lham / Pag lham

11. rKub 'thing

Source: Tenzin Dorji, Teacher Dungtse Middle Secondary School, Trashigang.

Like men, women also have their own set of costume. They wear mostly pink and white striped Shing ka (silk cloth) fastened with sash at waist. Plain white Shing ka is also used by few. Shing ka is formally lifted up to the height of shin or mid of calf (Chand, 2004, p. 72; Karchung, 2011) covered at buttock by sMad dkyigsm (a piece of plain woolen cloth usually black in colour attached over buttocks tied along with Shing ka up to knee). Other attires like sMad dkyigem, rTsid pa zha mo, and variety of sTod dung (thin jackets) such as; 'bu ras stod dung (thin jacket made of silk), Gzugs thing stod dung (fabric brocade), and Bal stod dung (woolen jacket). Over those sTod dungs, a piece of red square cloth (Lhem pa) woven of yak hair is worn to protect rain from seeping. Boots made either of wool or yak hair (Btsim lham or Mo lham) tied with Lham rogs (thin cord made either of animal skin or yak hair) are also used by women. They also put on magnificent ornaments to indicate their splendorous beauty (see Wangmo, 1990; Chand, 2004, pp. 70-74; Dompnier, 2007, pp. 38-41; Karchung, 2011). 

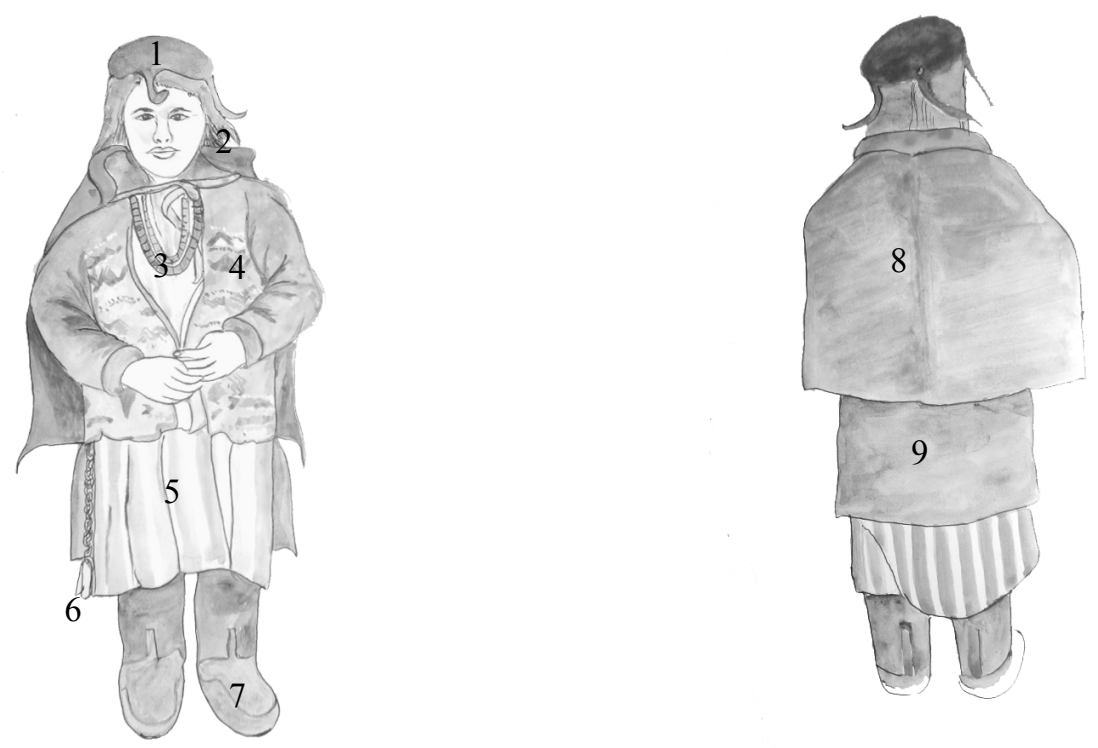

Figure 4. Female Drogpa costume

1. rTsid pa zha mo

2. rNam zao buma

3. sKae rgyn

4. sTod dung

5. Shing ka

6. Nga zor
7. bTsim lham / Mo lham

8. Lhem pa

9. sMad dkyigsm

Source: Tenzin Dorji, Teacher Dungtse Middle Secondary School, Trashigang

\section{2 'bru skor: An Antecedent Trading Custom}

'bru skor, meaning "moving around for grains" (Chand, 2000, 2004, pp. 93-96; Dorji, 2003, p. 38; Dompnier, 2007, pp. 32-37), is an enthralling trading custom that take place between Drogpa and their Nepo (winter hosts) from lower villages like Phongmed, Radhi, Ca gling, Bidung, Galing, Saling, Bartsam, Kanglung, Shingkhar and Lauri. Drogpa usually visit those villages that produce grains. The trading relationship between the Drogpa and their friends, the Sharchop Nepos last for almost three months whereby the Drogpa go around the villages by October to exchange their dairy products for food grains (Wangmo, 1990; Chand, 2000; Dorji, 2003, p. 38; Dompnier, 2007, pp. 32-37). 'bru skor is not just an economic necessities, rather it is their social tradition that is deemed crucial. Such social tradition has also brought them together with their Nepos and further promoted their trading custom.

\subsection{Festivals}

Various types of festivals are being held in the two Drogpa communities of Me rag and Sag steng every year. Some of the most popular festivals are: (1) Ache Lhamo, (2) Jomo Kora, (3) Mang Kurum, (4) Thoepa Gali, (5) Yak Cham, and (6) Tercham (Wangmo, 1990; Dompnier, 2007, pp. 56-69). A few of these festivals are considered of utmost significant because they happen only every three years. For instance, the Tercham of Sag steng, which is performed only every three years; it took place in the year (2012), and the next scheduled event is in 2015.

\subsection{Marriage Customs}

Marriage is another unique feature of Drogpa culture and traditions. The marriage custom of Drogpa is believed to have descended from the deity Ama Jomo Remanti (Dorji, 2002; Dorji, 2003, p. 39; Pelgen, 2003; Dompnier, 2007, pp. 42-44; Karchung, 2011). Dorji (2003, p. 39) believes that marriage customs of Drogpa originated from the wedding ceremony of Ama Jomo Remanti and Gomchen Khijey (later he was reborn as Blama Byara pas 
Horong). It is certain that Ama Jomo Remanti married and had three daughters and a son but with whom she married is still a mystery. sGrub dbang grags pa rjai btsun of rKang pa ra (rKang: foot; Pa ra; print) (Dompnier, 2007, pp. 72-75) is also popularly known as sLob dpon Khyi bzhis (alias) in eastern Bhutan who existed when Ama Jomo Remanti arrived in Bhutan. It is unclear whether Dorji (2003, p. 39) is referring sGrub dbang grags pa rjai btsun (alias sLob dpon Khyi bzhis) as Gomchen Khijey (Khyi bzhis) or he is talking about a different person. As per Dompnier (2007, pp. 72-75), sGrub dbang grags pa rjai btsun is the reincarnation of Prince Kintu Legpa; son of 'Mkha 'gardo 'grdo ba bzang mo and King 'Bka la dbang po of Tibet. In Dorji's monograph (2003, p. 39) one would also come across Gomchen Khijey who was later reborn as Blama Byara pas Horong.

All the available biographies mention only one Blama Byara pas who is also believed to be the reincarnation of Prince Kintu Legpa. This Blama Byara pas was the one who accompanied Ama Jomo Remanti and Drogpa to flee from Mtsho snar, Tibet. Therefore, a conclusion can be drawn that Gomchen Khijey referred by Dorji (2003, p. 39) is no other than sGrub dbang grags pa rjai btsun (alias sLob dpon Khyi bzhis) who also held the responsibility of converting Ama Jomo Remanti as the chief of all local deities. Therefore, there is no account that this sLob dpon Khyi bzhis married Ama Jomo Remanti (for details see Wangmo, 1990; Dompnier, 2007, pp. 72-75.).

Marriage custom of Drogpa is more of economic expediency rather than being a traditional dogma only (Wangmo, 1990; Chand, 2004, pp. 66-67). In this semi-nomadic society, parents and relatives play a vital role in arranging young couples to marry and to examine the couple's kinship relation, because it is considered culpable to marry parallel cousins (Wangmo, 1990). Cross cousin marriage is common in Eastern Bhutan (Dorji, 2002; Dorji, 2003, p. 39; Karchung, 2011) including in Me rag and Sag steng. Childhood engagement (Chung-gnyen) is also part of their marriage custom which is also practiced in lower Kheng of Zhemgang district (Dorji, 2003, p 1; Karchung, 2011). Childhood betroth happens when a child attains the age of eight or sometimes more (Dorji, 2002; Dompnier, 2007, p. 42). The parents of both children accept and encourage them to be married as adults, thus enhancing the family tie.

'khor sdeb pa (fraternal polyandry and polygamy) is another feature of marriage custom practiced among the Drogpa whereby a woman will marry more than one brother (husband) (Wangmo, 1990; Dutta, 2011; Wangchuk et al., 2013). Polygamy happens when a family has several daughters. Polygamous marriage system is rare in Me rag and Sag steng. "khor sdeb pa is practiced to prevent the outflow of wealth, fragmentation of the pasture land and need for more man power-aptly referred to as "getting a husband to support a husband" (Sommer, 2005, p. 29)-(Wangmo, 1990; Chand, 2004, p. 67; Dutta, 2011).

The existence of 'khor sdeb pa system within the Drogpa society of Me rag and Sag steng is little known to the people even though it is widely practiced in other parts of the world. However, such kind of marriage customs-Chung-gnyen and "khor sdeb pa-have diminished by now because youths prefer love marriage (cf. Karchung, 2011). Also, Drogpa are aware that childhood engagement is against the law. Fraternal polyandry and polygamy is also not proving a successful marriage in Me rag and Sag steng. In fact it is not doing well-tensions among the co-husbands-amongst the polyandrous societies (Carrasco, 1959, p. 36; Ekvall, 1968, p. 27; Goldstein, 1971; Cassidy \& Lee, 1989; Levine \& Silk, 1997; Willett, 1997; Haddix, 2001) whereby probability of partitioning is imminent.

Marriage customs of Drogpa are celebrated in three different phases (stages) (Wangmo, 1990; Dorji, 2002; Dorji, 2003, pp. 39-44; Chand, 2004, pp. 67-68; Dompnier, 2007, pp. 42-45). Matchmaker (Garpa gdong bsu) (Dorji, 2003, pp. 39-44; Dompnier, 2007, pp. 42-45) is chosen by the groom's parents (usually elders are selected considering their skills of communicating) to convey the proposal to bride's parents (cf. Wangmo, 1990; Karchung, 2011). Similarly, in the Ngenzhung marriage custom of Kheng regions of Zhemgang, matchmaker (Blon po Garwa tongthrab) plays a significant role. The custom of appointing Blon po Garwa tongthrab might have descendent from the marriage of Chos rgyal Srong btsan sgam po (r. 627 A.D-649 A.D). Chos rgyal Srong btsan sgam po appointed his minister Gar Tongtsen (as matchmaker) to go to China and find him a bride (Dorji, 2003, p. 3). Thence, any matchmaker in Kheng regions is called Blon po Garwa tongthrab. Therefore, the title of matchmakers (Garpa gdong bsu) of Me rag and Sag steng might have come from the minister's name Gar Tongtsen. However, both Blon po Garwa tongthrab and Garpa gdong bsu have one common principle that is functioning as a matchmaker.

Garpa gdong bsu will confer with astrologer (rTsis-pa) and fix the ceremony day for Trungchang (krung chang; drinks of acceptance) (Dorji, 2003, pp. 39-44; Dompnier, 2007, pp. 42-45), also known as Drichang (sGrig chang) (Wangmo, 1990). Duenchang (Mdun chang) used by Chand (2004, p. 67) to naming this ceremony is not a proper term. Of course it happens in big gathering; however it doesn't convey etymological meaning of first 
phase of marriage (Trungchang).

With Dkarchang (brewed grains filled in Tau ngama; copper vessel) and 2-3 palangs of Nagchang (arag, brewed grains filled in wooden jar; palang) Garpa gdong bsu and groom's parents will approach the bride's parents for matrimonial negotiation (Wangmo, 1990; Dorji, 2003, pp. 39-44; Dompnier, 2007, pp. 42-45; Karchung, 2011). While drinking Garpa gdong bsu performs his role (proposing bride's parents) through reciting verses. Refusal of marriage proposal is rare however with some exceptional cases. If the bride's parents are not satisfied as expected they decline the proposal. Refusal of proposal by the bride has to be compensated with rGyab chang and even foods (return drinks) (Wangmo, 1990; Dorji, 2003, pp. 39-44; Chand, 2004, p. 67; Dompnier, 2007, pp. 42-45). When bride's parents recommend groom's parents to arrange for the wedding it is an indication of acceptance.

Trungchang is then followed by another drinking ceremony, the Barchang (bar: middle; chang: drinks). This ceremony is the most significant one in which groom's parents commence to prepare plenty of brewed grains (arag: pronounced as ara), scarves and gifts (Dorji, 2003, pp. 39-44; Dompnier, 2007, pp. 42-45). The program starts with Dpah dar ceremony whereby groom's parents offer woven scarf (Pangkhep) to bride's parents and close relatives and white scarves are given to distant relatives (Dorji, 2003, p. 42; Dompnier, 2007, pp. 42-45). Groom's parents also offer white scarf to Garpa gdong bsu and Chang pa ama and drinks are provided to all. Garpa gdong bsu too offers scarves to bride's parents followed by reciting verses containing advices for bride and her parents. The advices conveyed through by Garpa gdong bsu are accepted by them (Wangmo, 1990; Dorji, 2003, pp. 39-44; Chand, 2004, p. 67; Dompnier, 2007, pp. 42-45).

Eventually, groom's and bride's parents prepare for the grand ceremony: Bagma gtong len, sending bride off. It takes place after two weeks or sometime even more depending on the convenience and readiness of groom's parents. Bagma gtong len is celebrated for three days commencing from bride's house and concludes at groom's house (Dorji, 2003, pp. 39-44; Dompnier, 2007, pp. 42-45).

For smooth functioning of the Bagma gtong len, the groom's parents make necessary arrangements like, Mgron bsu pa (guest master), two male Glu pa (singers), Gnyer pa (storekeeper), Thab tshang pa (cook), and Chang pa ama (drinks waitress). Glu pas sing songs for prosperous and happy marriage life and also eulogize Ama Jomo throughout three days of nuptials (ibid). Correspondingly, the rTsis-pa also performs ritual for the wellbeing of new couple.

Meanwhile, bride's parents prepare to send their daughter to groom's house. They give her gifts such as Btsim lham or mo lham, Jorzha mo (hat), Shing ka, and sTod dung (Dorji, 2003, pp. 39-44; Dompnier, 2007, pp. 42-45). At that time one of the bride's childhood friends will be sitting near to her as an assistant (Daw). She dresses up akin to bride. When the bride is taken off her home, it is a culture that she should cry and pretends to be sad (Wangmo, 1990; Dorji, 2003, pp. 39-44; Chand, 2004, p. 67; Dompnier, 2007, pp. 42-45).

\subsection{Migration and Herds}

Migration is one of the prominent traditional practices of Drogpa. However, one must bear in mind that all Drogpa do not migrate; only the herders (Nag rdze) migrate along with their herds of yaks and sheep (Chand, 2000; Dompnier, 2007, p. 36). Their livelihood depends entirely on these herds (Wangchuk et al., 2013). Generally, Drogpa follow two patterns of migration cycle-summer and winter (Gyamtsho, 2000; Tshering, 2004; Dompnier, 2007, pp. 36-37; Moktan et al., 2008; Wangchuk et al., 2013). In summer, they take their herds to high mountain pasturelands (above 4,500 meters) by May and let herds graze till end of October $( \pm 4$ months including autumn pasturing period). By September, they climb down for winter pasture where snowfall is exceptional and remain there for about 8 months until next migratory cycle (Gyamtsho, 2000; Chand, 2004, pp. 85-93; Tshering, 2004; Dompnier, 2007, pp. 36-37; Wangchuk et al., 2013).

Approximately $90 \%$ of the nomads living in the high mountain villages of Me rag and Sag steng depend on the pastureland for their livelihood, and the remaining people depend on those who have bigger herds (Dompnier, 2007, pp. 32-37; Wangchuk et al., 2013). Yaks and sheep are, therefore, the main sources of income (Chand, 2000; Dompnier, 2007, pp. 32-37; Moktan et al., 2008; Wangchuk et al., 2013) for all the Himalayan tribes if Bhutan. The young and energetic men and women of the family usually become Nag rdze (herders).

\section{The Drogpa Nature}

Drogpa are unique in appearance. They look rough and trace their origin from Tibet (sKom rLon Rogs gsum) (Chand, 2000, 2004, p. 29; Dompnier, 2007, p. 6). This ethnic group is very fond of their lifestyle, and they are of course very humorous. Consuming alcohol is part of their life, and people often become wild after getting drunk and get into quarrels (Dompnier, 2007, p. 6). Nonetheless, Drogpa never forget to be polite when they 
encounter people both known and unknown (Dompnier, 2007, p. 6). Drogpa are innocent in nature and, therefore, are not likely to change from what they are. They try to remain isolated to maintain as a homogeneous society (Chand, 2000). Generally, Drogpa are rigid and hardly accept the views of outsiders. They are also good at telling lies (Wangmo, 1990; Chand, 2000, 2004, p. 59).

Drogpa are also egotistic in nature. Therefore, compared to the past decades Drogpa behaviour is comparatively different at present (see Chand, 2000). Drogpa in the year 2000 were less receptive of modern development but now they demand roads to be constructed up to their villages regardless of government's repeated denial. They used to run away upon seeing visitors in the past.

Discourteous Drogpa behaviour is another challenging hindrance. For instance, under the initiative of Sag steng Wildlife Sanctuary (SWS) the Mac Author Foundation provided Corrugated Galvanized Iron (CGI) sheet to them. Almost all the Drogpa of Sag steng got the sheet and Drogpa of Me rag are getting it now. In order to maintain the traditional composition of the villages (Me rag \& Sag steng) one of the personnel of Mac Author Foundation recommended to roof houses with shingles (wooden planks) on top of CGI sheet. Drogpa initially agreed and also signed memorandum that is still intact in the office of SWS. However, now, when Drogpa are asked to abide by the memorandum they refuse and are appealing to government stating that it is very expensive to roof with shingles on top of CGI sheet. Deliberations on this issue are still going on. It is aptly mentioned by Wangmo (1990) and Chand (2000) that Drogpa always say 'laso' (ok) in front and never comply with what they said.

Another example be, whenever some Drogpa (not all) make gaffe they apologize stating 'we are people living in the forest and don't know anything' but on the contrary if any non Drogpa (especially civil servants) commits blunder they try to deal with them as per the laws.

\section{Effects of Globalization and the Undeniable Drogpa's Apprehension}

A negligible transformation within Drogpa society was observed by Chand (2000) when conducting research along with a few students of Sherubtse College, Kanglung, Trashigang. At the time, perhaps development had hardly reached Me rag and Sag steng, but Chand (2000) had noticed some changes already (see Dompnier, 2007, p. 1). By then the government of Bhutan has been putting in an effort to drag them into mainstream (Chand, 2004, p. 121).

Drogpa depend on herds of yaks and sheep for their livelihood (Chand, 2000; Dompnier, 2007, pp. 32-37; Moktan et al., 2008; Bhattarai et al., 2011; Wangchuk et al., 2013). They earn cash by selling the products of yaks and sheep such as woolen woven materials, cheese, butter, meat, and fermented cheese (Chand, 2000; Dompnier, 2007, pp. 33-34; Moktan et al., 2008). They trade their goods with the Drogpa of Tawang (Arunachal Pradesh, India) and the Sharchop friends (Wangmo, 1990; Chand, 2000; Dompnier, 2007, p. 37; Wangchuk et al., 2013). The mode of exchange then was mostly barter system (Chand, 2000; Dompnier, 2007, p. 37), and now, more paper money is being used (Moktan et al., 2008).

Today, the people of Me rag and Sag steng have access to various modern amenities such as electricity, television, cell phones, roads, and so on. As a result their culture, traditions, and Behaviour are changing profoundly every year. Therefore, the cultural and traditional homogeneity of the Drogpa is under a major shift. Williams (2002) shared his opinion in Bhutan Cultural Tours and Treks regarding the menace that Bhutan might encounter in the future as a result of modernization. He highlighted the cultural disintegration with the influx of television and the internet. Hosseini (2010) mentioned that most countries have lost their local cultural values with the intrusion of the mass media. He noted that the main factors of change are industries distributing cultural materials such as films, television, and news media.

Many changes can also be seen in the costumes of the Drogpa. The youths do not take much interest in wearing their own traditional costumes (Chand, 2000); rather, they like to wear pants and shirts, and very few school-goers wear Gho and Kira (national dress). In fact, even older Drogpa are seen in pants (Dor ma) and jackets. This is really an accelerating period of change caused by modern socio-economic development whereby the connection between the past and present is varying (Bhawuk, 2008). For instance, the Chu pa and Shing ka are being replaced by pants and shirts, and very few wear Gho and Kira. The shunning of traditional dress and culture by the young Drogpa is mentioned in the work of Chand (2000). Similarly, Pelgen (2003) encountered a Drogpa father who was on his way to meet his son studying at what was then the Radhi Lower Secondary School and today it is a middle secondary school. The father stated, "My son was ashamed to see me when I paid him a visit at Radhi Lower Secondary School, and I was received better by the teachers than my own son. I don't think he will ever come back to see me if he ever gets a job in the future" (Pelgen, 2003). This statement clearly indicates that the youth are not interested in their parents' culture and are looking for change. Many Drogpa youths today have developed bashful Behaviour and do not prefer to practice their rich and valuable culture and 
traditions.

The most striking and well-made leather boots known as sPu lham, Pag lham and Btsim lham or mo lham are being replaced by gum boots and other footwear imported from various countries. Indeed, these leather boots are not worn by Drogpa at all today with a few exceptional cases: mask dancers use them during festivals and a few older people continue to use. Therefore, the remarkable history of Drogpa costumes is diminishing along with their vanishing interest to wear their own attires (Karchung, 2011).

Me rag and Sag steng are integrated as tourist site in September 2010, thus exposing themselves to foreigners (Tourism Council of Bhutan (TCB), 2012, p. 10). Many foreigners come to Me rag and Sag steng to witness their pristine culture and traditions, especially the festivals. When more outsiders visiting every year, there is a potential risk that the environment might get polluted (Gurung \& Seeland, 2008). In continuum, Gurung and Seeland (2008) have mentioned that the Royal Government of Bhutan has an utmost concern about the promotion of culture and environment despite tourism development.

In addition, a few scholars viewed tourism also as a potential risk factor of acculturation (e.g., Groenfeldt, 2003; Chand, 2009). Chand (2000) stated that "the future of Drogpa society is in the hands of new generation Drogpa"; however, he observed that the young school-going Drogpa are not keenly interested in their own traditional costumes (Chand, 2000; Karchung, 2011). It is an early sign indicating that young Drogpa have changed behaviorally, and many changes can be seen today within the Drogpa society.

Although Bhutan has adopted various strategies (e.g., one of the GNH pillars; Preservation and Promotion of Cultures, Article 4 of the Constitution of Bhutan, National Library, Department of Culture) to promote and preserve its antecedent dynamic cultures and traditions, however, most of the indigenous cultural and traditional values are even more daunting, especially the Drogpa culture and traditions. Today many Drogpa children are fond of modern developments and perhaps they are very little or not at all aware of their own culture and traditions. For instance, one would hardly come across a youth who has a morsel of idea on their historical background (e.g., Drogpa origination). Even elderly Drogpa misinterpret their own history (e.g., Drogpa provide different interpretation on their costume origination). Indeed Drogpa history is preserved overwhelmingly in the manuscripts that are rarely available among the Drogpa. If these biographies are either lost or damaged than I am confident the Drogpa history will disappear and be manipulated.

Looking at the present transforming of the Drogpa, it is apparent that their dynamic culture and traditions losing its values. Both males and females are wearing pants and jackets instead of Chupa and Shingka. Youths on the other hand do not prefer to wear their costume at all. Therefore, the sustainable of Drogpa culture and traditions are not promising.

\section{Discussion}

The recent developmental activities in Me rag and Sag steng have brought changes in the lives of Drogpa. Such transformation is a likely threat to the culture and tradition of this semi nomadic people. Today, all the houses are being given access to electricity, and people have access to television and cell phones. People have started using electronic appliances to cook their meals, leaving behind their traditional methods of cooking. The construction of roads to Me rag and Sag steng is underway, which might bring more development and changes in these remote areas of Bhutan.

Tourism was also introduced in September 2010 by the Tourism Council of Bhutan under the recommendation of the $34^{\text {th }}$ Session of Lhuengye Zhungtshog (Council of Ministers/Cabinet Ministers) held on March 17, 2009 (TCB, 2012, pp. 7-9) to help people generate income through various means such as selling animal products, transporting luggage, and serving as labourer (Wangdi, 2012). According to TCB report (2012, p. 9) about $42.3 \%$ of the total people feel that animal husbandry is more beneficial than the tourism. In continuum, as of now less than $35 \%$ (65\% did not take part) of the people took part in tourism activities and eventually, majority of the respondent were of the view that tourism doesn't benefit their community (TCB, 2012, p. 14). Therefore the motive of TCB to benefiting the community is not felt same by the people. This might be because TCB is not providing equal opportunities to those communities who take part or either people don't want tourism at all. The report also says that people have understood the values of their own culture and traditions including heritages through the introduction of tourism in their region (TCB, 2012, p. 20). However, on the contrary, about $65 \%$ of the total population did not participate in tourism activity and indeed most of the respondents feel tourism as inefficient agent to their community (TCB, 2012, p. 14). This indicates that the people are not aware of what tourism is and for what purpose it is launched in Me rag and Sag steng. Eventually, we suggest that prior to commencing any new program in a region it would be better to seek the perception of those people first and let them understand the pros and cons of the program. 
Many Drogpa send their children to schools for higher studies, and some of them even send their children to pursue education in private schools within the country. On the other hand, in the study of Chand (2000), it was noted that many Drogpa parents were unwilling to send their children to school because they needed their children to look after the herds and support them. For instance, due to reluctance of Drogpa Sag steng Primary School (upgraded to Lower Secondary School in 2011) was closed for a decade. As a result, Dungpa Jigme Tenzin had to frame policy whereby children above seven years of age had to go to school compulsorily (Chand, 2000, 2004, p. 54). Thus, one can note here a sudden paradigm shift in the educational perception of the Drogpa. Jina (2002) also noticed similar changes in the habits of the Drogpa of Ladakh. To improve their children's future, these people are willing to provide higher education at different colleges in India.

The fear of losing Drogpa traditions and culture was noted in the works of Chand (2000) and Dompnier (2007, p. 2). They mentioned that, if proper planning is not undertaken, then the Drogpa culture may not survive in the future. With the intrusion of modern development, survival of the culture and traditions is difficult, although Bhutan has adopted an unusual system of developing the nation: Gross National Happiness (GNH; Groenfeldt, 2003; Karchung, 2011). Among the four pillars of GNH, one of them is the preservation and promotion of the culture (see McDonald, 2005; Karchung, 2011). Culture is, therefore, an indispensable element of identity among the communities of Bhutan (Dorji, 2008; Chophel, 2012). Chophel (2012) stated that change in cultural practice is associated with modern technologies; however, it depends on how one perceives those resources and how people use them. Development is subjected to both creating opportunities as well as change and thus induces risks to the cultural and the traditional values (Groenfeldt, 2003; Hosseini, 2010). In addition, Hosseini (2010) suggested that developing nations must emphasize better planning while adopting modern technology; otherwise, it will be difficult to maintain the unique culture and traditions.

The main factor pertaining to changing of the Drogpa culture and Behaviour is the modern development: (1) roads; (2) electricity; (3) modern education; (4) mobile facilities; and (5) television. Subramanyam and Moham (2006) concluded in their study that the mass media has played an important role in shaping the lives of tribal people. Of the various types of mass media, they found that television and film were very effective. They also noticed that tribal habitats exposed to road facilities are changing faster than those without it (Subramanyam \& Moham, 2006; Chand, 2009).

Therefore, an immediate holistic study should be carried out to determine and understand the impact of modern developments on the lives of Drogpa, their reaction, their concern about their cultural identity, and the measures implemented to promote and preserve the unique and vulnerable culture and traditions of Drogpa.

\section{Conclusion}

Future continuity of the Drogpa culture and traditions is uncertain if proper planning is not undertaken (Chand, 2000; Dompnier, 2007, p. 1). However, the fact is, with the recent intrusion of modern development, Drogpa have started changing steadily (cf. Karchung, 2011; Wangchuk et al., 2013). They have access to modern influencing facilities such as roads, television, cell phones, electricity, and electronic cooking appliances. Although the developmental planning in Bhutan is deeply associated with the philosophy of Gross National Happiness (Groenfeldt, 2003; McDonald, 2005; Karchung, 2011), the cultural hegemony of the Western world is uncompromising, which most of the developing countries find it difficult to avoid (Groenfeldt, 2003; Hosseini, 2010).

The present problems of Drogpa transformation (culturally and behaviorally) are not a complete distortion; however, it is an alarming issue for Drogpa themselves and for the nation. It is an enormous challenge for the country and Drogpa to preserve and promote their culture and traditions when globalization is underway. To a certain degree, the government of Bhutan is trying to maintain the continuity of the Drogpa culture through programs such as broadcasting Drogpa cultural practices on television and encouraging them to partake in and perform their traditional songs and dances on special occasions-e.g., National Day Celebration, $17^{\text {th }}$ December (Karchung, 2011).

Consequently, a need has arisen to study the perception of the Drogpa regarding modern development and the gross impact of development on the people of Me rag and Sag steng Accordingly, then, the government can plan for development activities as deemed necessary to bring them into mainstream. Also, the government should initiate to purchase their dairy products and sustain the livelihood of these people (Chand, 2000; cf. Wangchuk et al., 2013). 


\section{References}

Banerjee, I. (1998). Globalization and localization: Dynamic processes of cultural change. Asia Pacific Media Educator, 10(5), 119-129.

Bhattarai, S., Mense, S., \& Mitra, A. (2011). Nutritional status of the Drogpa: An anthropometric analysis. Sherub Doenme: The Research Journal of Sherubtse College, 11, 5-9.

Bhawuk, D. P. S. (2008). Globalization and indigenous cultures: Homogenization or differentiation? $\begin{array}{llll}\text { International Journal of Intercultural Relations, } & 32(4), & 305-217 .\end{array}$ http://dx.doi.org/10.1016/j.ijintrel.2008.06.002

Bowler, P. J. (1990). The invention of progress: The Victorians and the past. Cambridge, UK: Basil Blackwell.

Carrasco, P. (1959). Land and Polity in Tibet. Seattle: University of Washington Press.

Cassidy, M., \& Lee, G. R. (1989). The Study of Polyandry: A Critique and Synthesis. Journal of Comparative Studies, 20(1), 1-17.

Chand, R. (2000). Drogpa in transition: A study of tribal self-reliance in Bhutan. Sherub Doenme: The Research Journal of Sherubtse College, 5, 47-74.

Chand, R. (2004). The hidden highlanders of Bhutan. New Delhi: Phahar Publication.

Chand, R. (2009). Monpas of Bhutan: A study of tribal survival and development responses. Bulletin of Hiroshima University Museum, 1(6), 25-37.

Choden, K. (1997). Bhutanese Tales of the Yeti. Bangkok: White Lotus Press.

Chophel, S. (2012). Culture, public policy and happiness. Journal of Bhutanese Studies, 26, 82-99.

Dompnier, R. (2007). Traditions of the Drogpa of Me rag and Sag steng. Thimphu: Ministry of Home and Cultural Affairs.

Dorji, C. T. (2008). A concise cultural history of Bhutan. New Delhi: Prominent Publishers.

Dorji, L. (2003). Sergamathang Kothkin and other Bhutanese Marriage Customs (monograph). Thimphu: The Centre for Bhutan Studies.

Dorji, T. (2002). 'Brug shar phyogs pa'i gnyen lam brtsi stangs dang/bkra shis sgang phyogs kyi 'brog pagnyen sgrig gnyen sbyor bya tshul lo rgyus mdor bsdus na gzhon pho mo'i rna ba'i dpyid du gyur pa'i gtamdri za'i gling bu zhes bya ba bzhugs so (Marriage customs and practices of the Me rag Sag steng nomads ('brog pa) of Bkra shis sgang, Eastern Bhutan (in Tibetan)). Bulletin of Tibetology, 38(2), 39-60.

Dutta, J. (2011). Reading Yeshe Dorjee Thongchi's Sonam: A new historicist perspective. Journal of Literature, Culture and Media Studies, 3(5/6), 231-243.

Ekvall, R. B. (1968). Field on the hoof: Nexus of Tibetan nomadic pastoralism. New York: Rinehart and Winston.

Goldstein, M. C. (1971). Stratification, polyandry, and family structure in Tibet. Southwestern Journal of Anthropology, 27, 64-74.

Groenfeldt, D. (2003). The future of indigenous values: Cultural relativism in the face of economic development. Futures, 35, 917-929. http://dx.doi.org/10.1016/S0016-3287(03)00049-1

Gurung, D. B., \& Seeland, K. (2008). Ecotourism in Bhutan: Extending its benefits to rural communities. Annals of Tourism Research, 35(2), 489-508. http://dx.doi.org/10.1016/j.annals.2008.02.004

Gyamtsho, P. (2000). Economy of yak herders. Journal of Bhutanese Studies, 2(1), 90-135.

Haddix, K. A. (2001). Leaving your wife and your brothers: when polyandrous marriages fall apart. Evaluation and Human Behaviour, 22, 47-60. http://dx.doi.org/10.1016/S1090-5138(00)00061-1

Hosseini, H. (2010). Popular culture in Asia: Globalization, regionalization, and localization. Procedia Social and Behavioural Sciences, 2(5), 7356-7358. http://dx.doi.org/10.1016/j.sbspro.2010.05.094

Jina, P. S. (2002). Development of Ladakh Himalaya: Recent research. Satyawati Nagar : Kalpaz Publication.

Karchung, G. (2011). Diminishing Cultures of Bhutan: Costume of Merag Community. SAARC Culture, 2, $17-43$.

Kuensel. (2008). The Constitution of the Kingdom of Bhutan. Thimphu: Kuensel Corporation Ltd.

Levine, N. E., \& Silk, J. B. (1997). Why Polyandry Fails: Sources of Instability in Polyandry Marriages. Current Anthropology, 38(3), 375-398. http://dx.doi.org/10.1086/204624

Mancall, M. (2004). Gross National Happiness and Development: An Essay. In Ura \& Galay (Eds.), The Centre for Bhutan Studies (pp. 1-49). Thimphu: The Centre for Bhutan Studies.

McDonald, R. (2005). Towards a new conceptualization of Gross National Happiness and its foundations. Journal of Bhutan Studies, 12, 23-46. 
Moktan, M. R., Norbu, L., Nirola, H., Dukpa, K., Rai, T. B., \& Dorji, R. (2008). Ecological and social aspects of transhumant herding in Bhutan. Mountain Research and Development, 28(1), 41-48. http://dx.doi.org/10.1659/mrd.0802

Nehru, J. (2004). Glimpses of World History. New Delhi: Penguin Books India Pvt. Ltd.

Pelgen, U. (2003). Bhutan: Traditions and changes. Proceedings of the Tenth Seminar of the International Association for Tibetan Studies, 10(5), 121-134.

Sommer, M. H. (2005). Making Sex Work: Polyandry as a Survival Strategy in Qing Dynasty China. In B. Goodman \& W. Larson (Eds.), Gender in Motion: Divisions of Labor and Cultural Change in Late Imperial and Modern China (pp. 29-55). London: Rowman \& Littlefield Publishing Group, Inc.

Subramanyam, V., \& Mohan, K. R. R. (2006). Mass media and tribal life: A Study in Visakha Agency area of Andhra Pradesh. Journal of Anthropology, 8(2), 75-81.

Tourism Council of Bhutan (TCB). (2012). MeragSagsteng Impact Assessment Report. Thimphu: Planning and Research, Corporate Performance Department, Tourism Council of Bhutan.

Triandis, H. C. (2006). Cultural Aspects of Globalization. Journal of International Management, 12, $208-217$. http://dx.doi.org/10.1016/j.intman.2006.02.010

Tshering, C. (2004). Rangeland of Bhutan. Proceeding of the International Congress on Yak. Chengdu, Sichuan, P.R. China: IVIS publication.

Wangchuk, D., Dhammasaccakarn, W., Tepsing, P., \& Sakolnakarn, T. P. N. (2013). The Yaks: Heart and Soul of the Himalayan tribes of Bhutan. E3 Journal of Environmental Research and Management, 3(7), 189-196.

Wangmo, S. (1990). The Drogpa: A semi-nomadic people in Eastern Bhutan. In N. K. Rustomji \& C. Ramble (Eds.), Himalayan environment and culture (pp. 141-158). Shimla: Indian Institute of Advanced Study.

Willett, J. (1997). Tibetan Fraternal Polyandry: A Review of its Advantages and Breakdown. Nebraska Anthropologist, 113, 96-107.

Williams, P. (2002). Bhutan: A changing culture. Retrieved July 14, 2012, from http://www.bctt.com.bt/bhutanculture.php

Zangmo, T. (2004). Literacy for all: One of the means to Achieve Gross National Happiness. In Ura \& Galay (Eds.), The Centre for Bhutan Studies (pp. 629-636). Thimphu: The Centre for Bhutan Studies.

\section{Copyrights}

Copyright for this article is retained by the author(s), with first publication rights granted to the journal.

This is an open-access article distributed under the terms and conditions of the Creative Commons Attribution license (http://creativecommons.org/licenses/by/3.0/). 